\title{
Soil-Transmitted Helminth Infections, Anemia, and Undernutrition Among School-Children in An Elementary School in North Jakarta, Indonesia
}

\author{
Monica Puspa Sari, ${ }^{1}$ Tabita Nathasaria, ${ }^{1}$ Esther Sri Majawati, ${ }^{1}$ Helena Ullyartha Pangaribuan ${ }^{2}$ \\ ${ }^{1}$ Departement of Parasitologi, Faculty of Medicine and Health, Christian Krida Wacana University, Jakarta, \\ Indonesia, ${ }^{2}$ National Institute of Heath Research and Development, Ministry of Health Republic of Indonesia
}

\begin{abstract}
The strategy to control soil-transmitted helminth (STH) is through periodic deworming to eliminate infective worms among children. Helminthiasis is known to impair the nutrition and physical status of infected children. This study aimed to determine the prevalence and relationship between nutritional status and infection among School-Age Children (SAC) following deworming campaigns in Public Elementary School 6 Cilincing, North Jakarta, Indonesia. This study was a cross-sectional analytical observation on 82 children sampled using the Kato Katz approach during the period of August and November 2019. Nutritional status was determined using the standardized AnthroPlus Software while the Kolmogorov Smirnov test was used to statistically analyze the data. A structured questionnaire was used to collect data on hygiene and deworming pill consumption. Results showed that $7.3 \%$ of 82 children were infected with at least one of the following STH parasites: Ascaris lumbricoides accounts $(n=3,3.7 \%)$, Trichuris trichiura $(n=2,2.4 \%)$, and Enterobius vermicularis $(n=1,1.2 \%)$. Anemia was defined as a hemoglobin concentration of $<8-11.9 \mathrm{~g} / \mathrm{dL}$ for the age group of $8-13$ years old. Of all participants, $10(12 \%)$ were anemic. The proportion of children representing mild and moderate anemia were $4 \%$ and $6 \%$, respectively. The prevalence of infection was not associated with anemia and STH infection did not present significant association with undernutrition status. Almost children practiced hand washing before eating (93.9\%). About $96 \%$ of children had pit latrines and only 24 children (29.5\%) took deworming pills in the last 6 months. Thus, routine anthelminthic treatment for school children in urban areas is necessary.
\end{abstract}

Keywords: Children, nutritional status, North Jakarta, soil-transmitted helminths

\section{Infeksi Cacing yang ditularkan melalui Tanah, Anemia, dan Gizi Buruk pada Anak Sekolah Dasar di Jakarta Utara, Indonesia}

\begin{abstract}
Abstrak
Strategi pengendalian cacingan melalui pemberian obat cacing berkala untuk memberantas cacingan pada anak. Anak terinfeksi dapat mengalami gangguan gizi dan fisik. Penelitian bertujuan mengetahui prevalensi soil transmitted helminths (STH) dan hubungan status gizi anak sekolah pasca kampanye pemberantasan cacing di SDN 6 Cilincing, Jakarta Utara. Observasional analitik dengan desain studi potong lintang digunakan dalam sampel kato-katz dari 82 anak sekolah. Penelitian dilakukan dari Agustus-November 2019. Status gizi ditentukan menggunakan software AnthroPlus. Uji Kolmogorov Smirnov untuk menganalisis data. Hasil penelitian menunjukkan 7,3\% dari 82 anak terinfeksi setidaknya satu parasit STH. Parasit yang teridentifikasi, Ascaris lumbricoides sebanyak 3 (3,7\%). Trichuris trichiura 2 (2.4\%) diklasifikasikan infeksi ringan dan Enterobius vermicularis 1 (1,2\%). Anemia didefinisikan bila konsentrasi $\mathrm{Hb}<8-11,9 \mathrm{~g} / \mathrm{dL}$ untuk anak 8-13 tahun. Secara total, $10(12 \%)$ anak anemia. Proporsi anak mewakili anemia ringan dan sedang masing-masing adalah 4\%, dan $6 \%$. Prevalensi infeksi tidak berhubungan dengan anemia. Anak positif STH tidak menunjukkan hubungan yang signifikan dengan kekurangan gizi pada anak. Pengumpulan data kuesioner dilakukan menggunakan kuesioner terstruktur. Hampir semua anak mempraktikkan kebersihan tangan yang benar dan mencuci tangan sebelum makan (93,9\%). Memiliki jamban 96\% dan hanya 24 anak (29,5\%) minum obat cacing 6 bulan terakhir. Hasil ini mendukung antihelmintik rutin pada anak sekolah di daerah perkotaan.
\end{abstract}

Kata kunci : Anak, status nutrisi, Jakarta Utara, soil transmitted helminths

Corresponding Author: Monica Puspa Sari, Faculty of Medicine and Health, Christian Krida Wacana University, Jakarta, Jalan Arjuna Utara No. 2, Jakarta, Indonesia, Email:monica.puspasari@ukrida.ac.id 


\section{Introduction}

Helminthiasis has become one of the often underestimated and neglected tropical diseases. Soil-Transmitted Helminth (STH) is a common global helminth infection. Soil is a good medium for egg development that can affect human health, although it rarely causes death. The main species that infect people are roundworms (Ascaris lumbricoides), whipworms (Trichuris trichiura), and hookworms (Necator americanus and Ancylostoma duodenale). ${ }^{1}$

It is estimated that one-fourth of the global population has been affected by intestinal worms, which is common in Africa, America, and Asia. Preschool-age children (pre-SAC) and school-age children (SAC) are the most at risk to this infection. Approximately 270 million children of pre-SAC and 550 million SAC live in areas where worm infections are spreading. ${ }^{2}$

In Indonesia, STH infection is one of the primary public health problems with a prevalence ranging from $45 \%$ to $65 \%$. In areas with poor sanitation, the prevalence can reach as high as $80 \% .^{3}$ Mardiana et al. reported that Ascaris lumbricoides and Trichuris trichiura are the most common parasites of intestinal helminth infections in the Jakarta area. ${ }^{3}$ Another study conducted by Sari et al. in 2015 reported that about $40 \%$ of helminthiasis infections is caused by Ascaris lumbricoides and Trichuris trichiura, 38\% of which is in one area in North Jakarta. $^{4}$

The global goal is to eliminate morbidity due to STH in children by 2020 . To eliminate intestinal helminth infections, WHO has recommended several routine broad-spectrum drugs such as a single dose of $400 \mathrm{mg}$ albendazole that can be administered to primary school children to reduce intestinal helminth infections. ${ }^{5}$ Currently, treating school-age children with intestinal worms is indeed a priority; however, the preschool-age group is also at risk of infection and at a significant period of growth. To bear in mind is that the geographical heterogeneity of worm species in countries, communities, and individuals, where various STH species are often encountered, is a challenge for the implementation of this program. Given the lack of STH intervention studies, particularly in urban slums, there is a need for specific guidelines for the context of these areas, which comprise nearly one-third of the world's population. ${ }^{6}$

In children, the negative impact on nutritional status due to STH infection is high as it will lead to decreased food intake, malabsorption, and poor food digestion. ${ }^{7}$

Cilincing sub-district in North Jakarta is an urban and slum area that implements a periodic deworming program to control STH in SAC since 2018. Cilincing is a sub-district with the largest number of urban villages in the northern area of Jakarta. The sub-district is close to the coast. It is a fishing area with the majority of the population works as fishermen. Sari et al. in 2015 reported about $40 \%$ of helminthiasis infections caused by Ascaris lumbricoides and Trichuris trichiura, with around 38\% were observed in one area in North Jakarta. ${ }^{4}$ Also, the STH prevalence data are not available in this area and the deworming program was conducted without using a baseline data. For this reason, this study aimed to determine the prevalence of STH and its relationship with the nutritional status of children in Public Primary School 06 Cilincing after the deworming program.

\section{Methods}

An analytic observation within a cross-sectional study was carried out from August to November 2019 at the Public Primary School 06 Cilincing in North Jakarta. Samples were collected from students in grades 3-5 who were willing to participate and providing a fecal sample. The sample size was calculated using the following formula:

$$
\begin{aligned}
& n=\frac{Z_{1-\alpha / 2}^{2} P(1-P)}{d^{2}} \\
& \mathrm{n}=\frac{(1,96)^{2} \cdot \frac{0,24(1-0,24)}{(0,1)^{2}}}{\mathrm{n}}=\frac{3,8416 \cdot 0,24 \cdot 0,76}{0,01} \\
& \mathrm{n}=70 \text { people }
\end{aligned}
$$

An additional $10 \%$ of the total sample to predict the non-response. Thus, the minimum sample size was:

$$
\begin{aligned}
& n^{\prime}=\frac{\mathrm{n}}{1-\mathrm{f}} \\
& n^{\prime}=\frac{70=78}{1-0,1} \\
& n=80 \text { people }
\end{aligned}
$$

Children who agreed to participate in this study gave their stool samples and was treated with albendazole 400 if they were infected. Before sample collection, the researcher conducted health education, followed by explanation on how 
to collect stool samples in labeled containers, treatment, and informed consent. Collected stool containers were processed using the Kato-Katz technique. The subjects were assessed with anthropometrics, including body weight, height, hemoglobin examination using digital $\mathrm{Hb}$, and nutritional status assessment using z-score body mass index based on ages (BMI/U). Z-Score was calculated using the anthropometric calculator WHO Anthro Plus program. ${ }^{8}$ The questionnairebased data have been collected through a structured questionnaire on hygiene behaviors. Children were then classified as malnourished when they have a BMI that is less than a Z score $<-2$ (thinness and severe thinness). The infected children will be treated with a single dose of 400 mg ALB. All side effects will be observed and recorded.

Data were then analyzed using the Kolmoorov Smirnov Test to determine the relationship between nutritional status, anemia, and STH generated by the IBM Statistical Product for Social Science (SPSS) program version 25.0. This study has met the ethics requirements obtained from the Faculty of Medicine and Health, Christian Krida Wacana University numbered: 709/SLKE/IM/UKKW/FKIK/KE/III/2019.

\section{Results}

A total of 82 (with $85 \%$ response rate) school children were recruited in the present study. The children's age ranged from 8 to 13 years, and the majority of them were in the age groups of 8-10 (58.5\%) and 11-13 (34\%). Among these children, five children $(6.09 \%)$ were infected with STH and one child $(1.2 \%)$ were stated to be infected by Enterobius vermicularis. The prevalence of Ascaris lumbricoides and Trichuris trichiura was $3.7 \%$ and $2.4 \%$. The infections were all classified as mild. Neither mixed infections nor hookworm infections have been identified. Four girls were infected $(66.7 \%)$ and the majority of the infected children were $11-13$ years old $(66.7 \%)$ and four students $(66.7 \%)$ were in the 5 th grade. (Table 1).

From the total sampled population, the overall prevalence of STH infection, anemia, and undernutrition were $7.3 \%, 2.4 \%$, and $1.2 \%$, respectively. The predominant helminth species was A. lumbricoides (50\%), and the prevalent form of undernutrition was severe wasting.

Anthropometric analysis of body weight, height, and nutritional status using the Z-score or standard deviation classification system was carried out to determine the respondents' nutritional status in this study.

BMI for age is a significant indicator of underweight and obesity in older children. A crucial difference in the 2007 reference (WHO) for children from 5 to 19 years is the inclusion of BMI for age, now the preferred indicator for both obesity and underweight.

A total of 9 underweight children had a range weight and a height of 17.8-29 kg and 116.5$148.5 \mathrm{~cm}$, respectively. A total of 29 obese children with an average body weight of 22.4-68.3 and a height of 107-151.5 cm were identified.

Table 4 shows that 6 (six) infected children had the following nutritional status: 1 (one) child was categorized as severely malnourished, 3 (three)

Table 1 Subject Distribution and Characteristics

\begin{tabular}{|c|c|c|c|c|c|c|}
\hline \multirow{2}{*}{ Characteristic } & \multirow{2}{*}{ n (\%) } & \multirow{2}{*}{$\begin{array}{l}\text { Number of } \\
\text { Infected (\%) }\end{array}$} & \multicolumn{4}{|c|}{ Species } \\
\hline & & & A.I (\%) & T.t (\%) & HW(\%) & others $(\%)$ \\
\hline \multicolumn{7}{|l|}{ Sex } \\
\hline Male & $44(53.7)$ & $2(33,3)$ & $1(33,3)$ & $1(50.0)$ & $0(0.0)$ & $0(0.0)$ \\
\hline Female & $38(46.3)$ & $4(66.7)$ & $2(66,7)$ & $1(50.0)$ & $0(0.0)$ & $1(100.0)$ \\
\hline \multicolumn{7}{|l|}{ Age } \\
\hline $8-10$ & $48(58.5)$ & $2(33.3)$ & $1(33.3)$ & $0(0.0)$ & $0(0.0)$ & $1(100)$ \\
\hline $11-13$ & $34(41.5)$ & $4(66.7)$ & $2(66.7)$ & $2(100)$ & $0(0.0)$ & $0(0.0)$ \\
\hline \multicolumn{7}{|l|}{ Grade } \\
\hline III & $25(30.5)$ & $1(16.7)$ & $0(0.0)$ & $0(0.0)$ & $0(0.0)$ & $1(100.0)$ \\
\hline IV & $29(35.4)$ & $1(16.7)$ & $1(33.3)$ & $0(0.0)$ & $0(0.0)$ & $0(0.0)$ \\
\hline $\mathrm{V}$ & $28(34.1)$ & $4(66.7)$ & $2(66.7)$ & $2(100.0)$ & $0(0.0)$ & $0(0.0)$ \\
\hline
\end{tabular}

A.l= Ascaris lumbricoides, T.t $=$ Trichuris trichiura, $\mathrm{HW}=$ Hookworms 
Table 2 Prevalence of STH infection, anemia, and undernutrition among schoolchildren in Public Primary School 6 Cilincing, North Jakarta, Indonesia, in 2019

\begin{tabular}{lcc}
\hline Variable & $\begin{array}{c}\text { Number of } \\
\text { Infection (\%) }\end{array}$ & P-value \\
\hline STH infection & $3(50)$ & NA \\
Lumbricoides & $2(33)$ & \\
T. trichiura & $1(17)$ & \\
E. vermicularis & & \\
Anaemia & $2(33)$ & \\
Yes & $4(67)$ & \\
No & $1(17)$ & 0.903 \\
Undernutrition & $5(83)$ & \\
Yes & \\
No & \\
Type of & \\
undernutrition & \\
Severe thinness & \\
Thinness &
\end{tabular}

were normal, and 2 (two) were overweight. The statistical test presented $\mathrm{p}=0.903(\mathrm{p}>0.05)$ when analyzedusing the Kolmogorov-Smirnov. Therefore, it was concluded that there was no significant association between helminth infection and nutritional status (BMI-based).

Overall, anemia occurred in $10 \%$ of the children. Two infected children (66.7)\% experienced while the remaining were $5.4 \%$ normal. Statistical results using the KolmogorovSmirnov obtained $p=1.000(p>0.05)$. There was no significant association between the STH infection and anemia incidence. Although not statistically significant, the moderate anemia was seen in $5(6 \%)$ non-infected children and 4 (4\%) infected children had a normal Hb level.

Children infected with STH and Enterobius vermicularis were immediately treated with a single dose of $400 \mathrm{mg}$ albendazole. Some children experienced adverse events such as diarrhea in 2 (two) children (33.3\%), dizziness in 1 (one) child (16.7\%), and nausea in 1 (one) child $(16.7 \%)$.

Table 6 lists the hand hygiene and prevention behaviors, in which almost all children practiced proper hand hygiene, namely washing hands

Table 3 Nutritional Status Category of Respondents

\begin{tabular}{lcccc}
\hline \multicolumn{1}{c}{$\begin{array}{c}\text { Nutritional Status } \\
\text { Category }\end{array}$} & $\mathbf{n}$ & $\begin{array}{c}\text { Weight (kg) } \\
\text { Median (range) }\end{array}$ & $\begin{array}{c}\text { Height (cm) } \\
\text { Median (range) }\end{array}$ & Z-score \\
\hline Severe Thinness & 6 & 11.05 & & \\
& & $(21.1-24.6)$ & $(129-145.5)$ & $<-3$ SD \\
Thinnes & 3 & 9.4 & 58.75 & -3 SD up to $<$ \\
\multirow{2}{*}{ Normal } & & $(17.8-29)$ & $(116.5-148.5)$ & -2 SD \\
\multirow{2}{*}{ Overweight } & 44 & 9.55 & 51.5 & -2 SD up to 1 \\
& & $(17.1-38.1)$ & $(100-150)$ & SD \\
Obesity & 23 & 11.7 & 54.5 & $>1$ SD up to 2 \\
& \multirow{2}{*}{6} & $(22.4-58.5)$ & $(107-151.5)$ & SD \\
& & $(37.2-68.3)$ & $(117.5-148)$ & $>2$ SD \\
\hline
\end{tabular}

SD=Standard Deviation

Table 4 Nutritional Status and Intestinal Helminth Infection

\begin{tabular}{|c|c|c|c|c|c|c|c|c|c|c|c|}
\hline \multirow{3}{*}{$\begin{array}{l}\text { Intestinal } \\
\text { Helminth } \\
\text { Infection }\end{array}$} & \multicolumn{10}{|c|}{ Nutritional Status } & \multirow{3}{*}{$\mathbf{p}$} \\
\hline & \multicolumn{2}{|c|}{ Normal } & \multicolumn{2}{|c|}{ Thinnes } & \multicolumn{2}{|c|}{$\begin{array}{c}\text { Severe } \\
\text { Thinness }\end{array}$} & \multicolumn{2}{|c|}{ Overweight } & \multicolumn{2}{|c|}{ Obesity } & \\
\hline & $\mathbf{n}$ & $\%$ & $\mathbf{n}$ & $\%$ & $\mathbf{n}$ & $\%$ & $\mathbf{n}$ & $\%$ & $\mathbf{n}$ & $\%$ & \\
\hline Negative & 41 & 93.18 & 6 & 100.0 & 2 & 66.67 & 21 & 91.30 & 6 & 100.0 & 0.903 \\
\hline Positive & 3 & 50 & 0 & 0.0 & 1 & 16.7 & 2 & 33.3 & 0 & 0.0 & \\
\hline Total & 44 & 100.0 & 6 & 100.0 & 3 & 100.0 & 23 & 100.0 & 6 & 100.0 & \\
\hline
\end{tabular}


Table 5 Anemia and Intestinal Helminth Infections

\begin{tabular}{|c|c|c|c|c|c|c|c|}
\hline \multirow{3}{*}{$\begin{array}{l}\text { Intestinal } \\
\text { Helminth } \\
\text { Infection }\end{array}$} & \multicolumn{6}{|c|}{ Anaemia } & \multirow{3}{*}{$\mathbf{p}$} \\
\hline & \multicolumn{2}{|c|}{$\begin{array}{l}\text { Normal } \\
(\mathrm{Hb} \geq 12\end{array}$} & \multicolumn{2}{|c|}{$\begin{array}{l}\text { Mild Anaemia } \\
\text { (Hb 11-11.9) }\end{array}$} & \multicolumn{2}{|c|}{$\begin{array}{c}\text { Moderate Anaemia } \\
\text { (Hb 8-10.9) }\end{array}$} & \\
\hline & $n=74$ & $\%$ & $n=3$ & $\%$ & $n=5$ & $\%$ & \\
\hline Negative & 70 & 94.6 & 1 & 33.3 & 5 & 100.0 & \multirow{2}{*}{1.000} \\
\hline Positive & 4 & 5.4 & 2 & 66.7 & 0 & 0.0 & \\
\hline
\end{tabular}

before eating food (93.9\%), after defecation $(92.7 \%)$, and after playing with soil $(80.5 \%)$. Meanwhile, $96 \%$ of the children had pit latrines. Of the $96.3 \%$ of children, $80 \%$ wore footwear and nail clippings once a week. Only 24 children (29.5\%) took deworming pills in the last six months. The result found that some of these children had been infected with intestinal worms, despite practicing hand hygiene.

\section{Discussion}

This study revealed that the STH prevalence in Cilincing, North Jakarta, among school children is $7.3 \%$. This number has decreased compared to that of the previous years. This decrease is due to the annual deworming program of targeted SAC and pre SAC that has reduced STH with low infection intensity in accordance

Table 6 Distribution of Hand Hygiene and Prevention behavior

\begin{tabular}{llcc}
\hline \multicolumn{1}{c}{ Health Behaviour } & \multicolumn{1}{c}{ Answer } & $\mathbf{n ~ ( \% )}$ & Infected (\%) \\
\hline Washing hands before eating food & Yes & $77(93.9)$ & $5(83.3)$ \\
How to handwash & No & $5(6.1)$ & $1(16.7)$ \\
Washing hand After defecation & Water and soap & $61(74.4)$ & $4(66.7)$ \\
& Water & $21(25.6)$ & $2(33.3)$ \\
How to handwash & Yes & $80(97.6)$ & $6(100.0)$ \\
Washing hand after playing with soil & No & $2(2.4)$ & $0(0.0)$ \\
& Water and soap & $76(92.7)$ & $5(83.3)$ \\
How to handwash & Water & $6(7.3)$ & $1(16.7)$ \\
Wearing foot wear & No & $66(80.5)$ & $4(66.7)$ \\
& Water and soap & $68(82.9)$ & $2(33.3)$ \\
Nails clipping (once a week) & Water & $14(17.1)$ & $2(33.3)$ \\
Pit latrine & Yes & $74(90.2)$ & $6(100.0)$ \\
Take a worm pill for at least the last 6 & No & $8(9.8)$ & $0(0.0)$ \\
months & Yes & $65(79.3)$ & $5(83.3)$ \\
\hline & No & $17(20.7)$ & $1(16.7)$ \\
& No & $79(96.3)$ & $6(100.0)$ \\
& Yes & $3(3.7)$ & $0(0.0)$ \\
& No & $24(29.3)$ & $1(16.7)$ \\
& & $58(70.7)$ & $5(83.3)$ \\
\hline
\end{tabular}


with WHO criteria. This statement is consistent with several studies that showed decreasing helminth infection in several areas in Indonesia, as reported by Anninda et al. ${ }^{9}$, in the sub-district of Loksado, Hulu Sungai Selatan District, South Kalimantan, showing a $6.8 \%$ of STH prevalence. Different risks for each study site, particularly in environmental sanitation, personal hygiene, age, sex, socio-economic aspects, knowledge level, food, and water resources sanitation, and natural or geographic conditions, can influence the differences in the prevalence of STH in the studies in each of the above areas. Children often play and get in direct contact with the soil. For instance, they do not wear footwear when playing, wash their hands, and have long nails. It makes parasites easily penetrate the children's body, which is exacerbated by living in slums or heavily populated areas. ${ }^{10}$

Children infected with STH, based on their nutritional status, are well-nourished and even overweighted. Statistical tests have shown no correlation between nutritional status infection with a p-value of 0.903 ( $p>0.05)$. It is in accordance with studies by Singgih and Song ${ }^{11}$ in 2015-2016, declaring that many normal nutritional children have been infected with one of the causes of STH, such as Ascaris lumbricoides. In this research, a P-value of $4.096(\mathrm{p}<0.05)$ is also reported.Conversely, a study by Annisa et al. in Palembang showed that up to 18 (62.1\%) have been infected with $p=0.037(\mathrm{p}<0.05)$ of underweight nutrition. ${ }^{10}$ Various factors, such as the parents' economic level, hygiene, unbalanced food intake, chronic infection, and parenting can influence the relation between STH infection and nutrition status. ${ }^{11}$ These discrepancies can be justified by differences in sample size and behavioral differences across different settings.

This study result contradicts other studies, which demonstrate a relationship between nutritional status and STH. In this study, all children have a clean and healthy behavior, where the STH infection status in this area is considered mild. Also, STH infection can cause a decrease in nutritional status if the STH infection has been chronic and prolonged. This finding is consistent with Shang Yu et al. ${ }^{12}$ who revealed STH infection, is one of the major risk factors for stunting, with moderate to heavy intensity infections being the main predictor of stunting. Additional information from the city health office stated that the Cilincing sub-district has initiated the deworming program among SAC and preSAC since 2018 up to now. The primary and currently most realistic aim of such mass drug administration (MDA) is to control morbidity due to STH by reducing infection intensity and, ultimately, prevalence. ${ }^{13}$

Moreover, Taylor, ${ }^{14}$ in the review paper, stated the thinking for the effect of deworming programs on population development is based on the assumption that reducing the burden of worms in the population will lead to improved nutritional status and potential increases in hemoglobin and cognition. As a result of these benefits, children are perceived to experience increased physical well-being, increased intelligence, and can attend school more often.

As shown in Table 5, participants who were infected with STH infection had a normal level of $\mathrm{Hb}(66.7 \%)$ and there was an insignificant association between infection and anemia level, with a $p$-value of $1.000(\mathrm{p}>0,05)$. In East Lombok, Hayati et al. reported that many children infected with helminthiasis have $\mathrm{Hb}$ normal level, with $p$-value $=0.091(\mathrm{p}<0.05) .{ }^{15}$ This study reported an association between STH and Anemia, which is in contrast to the findings of Aji et al. ${ }^{16}$ in Palembang.The nutritional status and hemoglobin of the children are not only affected by helminth infection. Helminth infection takes a long time to influence and reduce the $\mathrm{Hb}$ levels of a human host. ${ }^{15}$ Among STH species, $T$ trichiura and hookworm are the cause of anemia. In this study, no infection due to hookworm was found, and only two children were infected with $T$ trichiura. Besides, anemia is also caused by several other factors, such as iron deficiency, impaired iron absorption, and improper diet pattern. ${ }^{17}$ Ascaris lumbricoides infection is commonly asymptomatic or may produce mild, non-specific symptoms. ${ }^{18}$

The findings of the questionnaire-based data on hygiene behaviors revealed that children have adopted clean and healthy behavior, but they are not entirely free from the risks of intestinal infection. Bias may occur because the responses do not adequately represent daily behaviors, such as not practicing proper hand hygiene. It is also because the responses are subjective so that the questions cannot be properly understood. To adopt healthy lifestyles, children should exercise proper hand hygiene by using tap water and soap to prevent STH eggs from sticking to the skin and nails. ${ }^{19}$ Nizame et al. $^{20}$ finding in Bangladesh, 2015, may be used in a further study that demonstrated qualitative investigation to explore perceptions and practices of handwashing and use of handwashing agents including observed handwashing practices based on structured observations. 
The limitations of this study may be due to the sample size and sampling areas or other risk factor variables that contribute more to the development of STH infections.

In conclusion, there is no significant relationship between STH infection and nutritional status in this study. The STH prevalence of $7.3 \%$ with low infection intensity indicates a deworming program with ALB among school children is very useful for controlling intestinal helminth. Also, data suggested that the prevalence of anemia is not significantly dependent on STH infection. Regular health education for school children on proper handwashing is paramount to prevent the transmission of various infectious diseases, including intestinal helminth. This study revealed that a deworming program is effective in reducing STH transmission among SAC. However, further studies are recommended in urban areas using the Probability Proportional to Size (PPS) sampling to determine the impact of deworming programs among pre-SAC or SAC and risk factors such as behaviors of food handling in school canteens or food-handling in street food sales.

\section{Acknowledgement}

The authors would like to express their gratitude to the Public Primary School 6 Cilincing, North Jakarta, Indonesia and all children for supporting and participating in this study.

\section{References}

1. Hotez PJ, Bundy DAP, Beegle K, Brooker S, Drake L, Silva ND, et al. Helminth infections: soil-transmitted helminth infections and schistosomiasis. In: Jamison DT, Breman JG, Measham AR, Alleyne G, Claeson M, Evans $\mathrm{DB}$, editor. Disease control of priorities in developing countries. 2th ed. New York: Oxford University Press; 2004. p. 467-82.

2. WHO. WHO guideline: preventive chemotherapy to control soil-transmitted helminth infections in at-risk population groups, 2017. World Health Organization; 2017.

3. Nasution RKA, Nasution BB, Lubis M, Lubis IND. Prevalence and knowledge of soil-transmitted helminth infections in Mandailing Natal, North Sumatera, Indonesia. Open Access Maced J Med Sci.
2019;7(20):3443-46.

4. Sari MP, Supali T, Wibowo H. Perbandingan uji diagnostik mini flotac dengan kato katz sebelum dan sesudah pengobatan albendazol dosis tunggal pada anak yang terinfeksi cacing usus. J Kedokt Meditek. 2015;21(55):1-7.

5. Legge H, Kepha S, Prochazka M, Halliday K, Pullan R, Chore MCG, et al. Implementer and recipient perspectives of community-wide mass drugadministrationfor soil-transmitted helminths in Kwale County, Kenya. PLoS Negl Trop Dis. 2020;14(4):e0008258.

6. Suchdev PS, Davis SM, Bartoces M, Ruth LJ, Worrell CM, Kanyi H, et al. Soil transmitted helminth infection and nutritional status among urban slum children in Kenya. Am J Trop Med Hyg. 2014;90(2):299-305.

7. Wong WK, Foo PC, Roze MNM, Pim CD, Subramaniam P, Lim BH. Helminthic infection and nutritional studies among orang asli children in sekolah kebangsaan Pos Legap, Perak. Can J Infect Dis Med Microbiol. 2016;2016.

8. WHO. Growth reference data for 5-19 years: WHO anthroplus for personal computers manual: software for assessing growth of the world's children and adolescents. 2007. Published 2007. Accessed [July 23, 2020]. Available from: https://www.who.int/ growthref/who2007_bmi_for_age/en/.

9. Annida A, Fakhrizal D, Juhairiyah J, Hairani B. Gambaran status gizi dan faktor risiko kecacingan pada anak cacingan di masyarakat Dayak Meratus, Kecamatan Loksado, Kabupaten Hulu Sungai Selatan. J Heal Epidemiol Commun Dis. 2019;4(2):5464.

10. Anwar C, Annisa S, Dalilah D, Novrikasariet. The relationship between soil transmitted helminthes (STH) infection and nutritional status in students of state elementary school number (SDN) 200 Palembang Indonesia. Biosci Med J Biomed Transl Res. 2018;2(2):42-53.

11. Singgih R, Song C. Hubungan status infeksi askariasis dengan status gizi anak di komunitas sahabat anak area Jakarta Barat periode 2015-2016. Tarumanegara Medical Journal. 2019;2(1):148-51.

12. Shang Yu, Tang LH, Zhou SS, Chen YD, Yang YC, Lin SX. Stunting and soil-transmitted helminth infections among school-age pupils in rural areas of Southern China. Parasites and Vectors. 2010;3(97):1-6.

13. WHO. Soil-transmitted helminths: 
Eliminating soil-transmitted helminthiases as a public 808 health problem in children. Progress report 2001-2010 and strategic plan 2011-2020. Available from: http:// whqlibdoc.who.int/publications / 2012 / 9789241503129_eng.pdf.

14. Taylor-Robinson DC, Maayan N, Donegan S, Chaplin M, Garner P. Public health deworming programmes for soil-transmitted helminths in children living in endemic areas. Cochrane Database Syst Rev. 2019;9(9):CD000371.

15. Hayati Z, Anggoro J, Y EA. Hubungan infeksi cacing usus terhadap Anaemia defisiensi besi pada siswa sekolah dasar kelas V Dan VI di Desa Dasan Lekong Kecamatan Sukamulia Kabupaten Lombok Timur Tahun 2011. J Kedokt. 2013;2(2):1-9.

16. Aji DP, Garini A, Hermansyah H. Hubungan infeksi soil transmitted helminth dengan Anaemia pada siswa sekolah dasar di kecamatan gandus kota palembang tahun 2016. Jurnal Kesehatan Poltekkes Palembang.
2017;12(1):59-62.

17. Azizaturridha A, Istiana I, Hayatie L. Pengaruh infeksi kecacingan terhadap status gizi pada anak Di Sdn 2 Barabai Darat Kalimantan Selatan Tahun 2015. Berk Kedokt. 2016;12(2):165.

18. Jourdan PM, Lamberton PHL, Fenwick A, Addiss DG. Soil-transmitted helminth infections. Lancet. 2018;391(10117):25265.

19. Chadijah S, Sumolang PPF, Veridiana NN. Hubungan pengetahuan, perilaku, dan sanitasi lingkungan dengan angka kecacingan pada anak sekolah dasar Di Kota Palu. Media Penelit dan Pengemb Kesehat. 2014;24(1):50-6.

20. Nizame FA, Nasreen S, Halder AK, Arman $\mathrm{S}$, Winch PJ, Unicomb $\mathrm{L}$, et al. Observed practices and perceived advantages of different hand cleansing agents in rural Bangladesh: Ash, soil, and soap. Am J Trop Med Hyg. 2015;92(6):111. 